\title{
Akbari and Asghari Reappear
}

As the previous chapter showed, mass schooling in Pakistan has become one of the most dominant societal institutions for the reproduction of the next generation of citizen-subjects. Schools have taken over some of the key roles around the nurturing and instruction of young people that were previously reserved for the family and religious authorities. This has led to contestations around appropriate training of young people and the reassertion of the role of the home and/or alternate educative institutions in the cultural and ethical formation of the child. Education, thus, has transformed into a densely contested field with multiple actors-the state, the family, religious institutions, as well as mass media-seeking to define ideal subjectivities and proper relationships that young people must have to the state, home, waged work, the opposite sex, and religion. These relationships are important because they are the means in and through which economic and cultural privileges are reproduced and new ones accessed, and identities reinforced and remade. Against this background, in the current chapter I explore televised visualities, which prescribe and prohibit particular forms of femininity.

As forms of "public pedagogies," viewers about certain possible subjectivities, while simultaneously reproducing and resisting others. In the immediate aftermath of Pakistan's political independence, television programming was closely tied to nationalistic interests. However, the wider availability of television sets and the entrance of numerous private television networks in recent decades has enabled diverse programming. Television today forms one of the most accessible and influential discursive spaces that mediates social imaginaries. Hence, I see a television production as yet another kind of "text" in a genealogy that functions as an "actant" within a social system. While a 
plurality of voices in television means that there is a simultaneous reproduction and subversion of relations of power, television as a technology and cultural text is closely tied to urban and middle-class sensibilities in the context of Pakistan. The writers and producers of television shows, as well as owners of television networks, often come primarily from middle-class, urban backgrounds, and have exposure to transnational issues, which influences the representational practices of television. Hence, in the context of this book, which is attempting to explore distinctly middle-class tensions around the construction of the ideal girlhood, television is an apt medium to analyze. Furthermore, even with the entry of private networks, the state continues to harness television-by influencing it through advertisement dollars as well as through censorship practices-for its national integration and development goals. Television, thus, plays a complex role in social reproduction and critique.

Specifically, I have selected two recent televised shows that are based on Nazir Ahmed's popular novel Mirat-ul-uroos (The Bride's Mirror), which as we saw earlier was first published in 1869. Attending to the reproduction of Mirat-ul-uroos with its representation of ideal versus failed femininities facilitates a tracing of the kinds of lives that are authorized/normalized in contemporary Pakistan as well as the ones that are marked as deficient. It also helps to explicate the role of the family, religious ideologies, and school in crafting girlhoods. I will argue that through these representational practices television not only inculcates middle-class mores that reproduce the patrilineal family but also demarcates the home as the site for moral instruction (tarbiyat) and schools as places where education (talim) linked to waged work takes place.

\section{ADAPTATIONS OF MIRAT-UL-UROOS}

In Mirat-ul-uroos Nazir Ahmed explicated desired and failed sharif femininities through the contrasting figures of Akbari and Asghari. While the older sister, Akbari, personified recklessness, petulance, and greed, the younger sister, Asghari, was shown to be intelligent and thoughtful. It is Asghari's intentional privileging of the welfare of the patriarchal family that gains her the respect of not only her male relations but also her neighbors. She later starts a home-based school where other sharif families send their daughters so that they can emulate her. As mentioned earlier, Nazir Ahmed's book was picked up by the Department of Public Instruction, awarded a prize, and circulated to public schools. What is remarkable, however, is that the text has not lost its potency; it remains in circulation even today in India and Pakistan. Many girls receive this text as a gift at the time of their wedding, which signals its broad appeal. Furthermore, the binary subject positions represented by Asghari and Akbari have come to inform everyday lexicon. Consider an opinion piece published in 2013 in the Pakistani newspaper 
the Express Tribune, entitled, "Seeing Each Other in Black and White."2 In the article, the author criticizes the tendency of Pakistanis to see everything "in black and white," naming it as the "Akbari and Asghari mentality" and the "Akbari/ Asghari lens." Akbari and Asghari, thus, continue to be relevant frames of legibility in the context of Pakistan today. In fact, Mirat-ul-uroos has been adapted for Pakistani television at least three times in the recent past: during the 1990 for the Pakistan Television Network, in 2011 for HUM TV, and in 2012 for Geo TV. In this chapter, I examine the representational practices of the HUM TV and Geo TV productions.

The Hum TV production Akbari Asghari (2011) is based on Mirat-ul-uroos, but rewritten as a comedy by the novelist Faiza Iftikhar. ${ }^{3}$ Here, the protagonists-Akbari (also known as Becky) and Asghari (also known as Sara) - grow up in England and return to their family's village in Punjab, Pakistan, to marry their cousins, Akbar and Asghar, to whom they were betrothed when young. The comedy centers on the sisters' struggle to find a sense of belonging in the new environment. The $\mathbf{2 0 1 2}$ Geo TV production of Mirat-ul-uroos, on the other hand, retains the original title. ${ }^{4}$ This production revolves around Akbari's granddaughters, Aiza and Aima, who get married to Asghari's grandsons, Hammad and Hashim. Aiza, raised by Akbari, mirrors some of her values, while Aima reflects a thoughtfulness and maturity that is reminiscent of Asghari (even though she was not raised by her). These systematicities in characters help the viewers to readily assimilate Aiza, Aima, Becky, and Sara into familiar binary frames of desired/failed female subjects.

In both the Hum TV and Geo TV productions there are intense negotiations around performances of ideal femininities, which are linked to prevailing anxieties and aspirations around middle-classness. For instance, in the Geo TV production, through the characters of Aima and Aiza, we learn about economic pressures linked to rising inflation, unemployment (particularly of men), and the high cost of English-medium education. ${ }^{5}$ Such pressures impinge upon the ability of Pakistani middle-class families to reproduce themselves culturally, as is evident by the discussion of extensive dowries for girls, living in a joint-patrilineal family arrangement, and tensions around women's entrance into waged work. The Geo TV production, then, teaches its viewers about habits and behaviors that are necessary for sustaining and reproducing middle-classness. It calls upon its viewers, particularly Pakistani middle-class women, to reinvent themselves in specific ways if they wish to continue to enjoy middle-class privileges and the familial harmony that accompanies such stable economic grounding.

The HUM TV production also explores economic precarities but does so through the theme of transnational migration. Here, middle-class identity is expressed through cultural mores and linguistic affiliations. To assert authenticity, many characters attempt to speak in Punjabi and Urdu, as well as English to varying degrees, which signals their comfort with, or aspirations for, middle-class social norms. Becky and Sara's family in England is shown to be working-class, 
which creates pressures for the sisters to find waged work, a practice that is read as a compulsion. Thus, both television shows give a glimpse into the local, national, and transnational forces that are shaping possible subject positions for women (and men) in Pakistan and the diaspora.

The fact that the two television shows are based on a nineteenth-century text shows how the present is neither a continuation nor a radical rupture from the past-rather, the relationship across gender, education, social class, the patriarchal family, and the nation continues to modulate in different ways. Women and girls continue to emerge as key players in reproducing middle-classness economically as well as culturally, and the ideal, educated woman is one who can perform this role adeptly.

\section{THE ECONOMIC AND CULTURAL REPRODUCTION OF}

\section{THE MIDDLE CLASS}

One of the key framing themes in Mirat-ul-uroos (2012) is the economic precarity of middle-class families, and the role educated women are to perform to preserve familial economic and cultural status. The contrasting figures of Aima and Aiza symbolize modes of being that can either reproduce or threaten middle-classness. In this context, social class is theorized not simply as an economic position but also as a set of cultural mores, which include consumption habits, orientation toward waged work, and relations with the opposite sex and servants. In taking up these topics, Mirat-ul-uroos (2012) prescribes feminine performances crucial for the preservation of both economic and cultural middle-class status. Significantly, moral instruction, which takes place in the context of the home rather than the school, is elevated as the essential social practice that can transform girls into ideal subjects. In other words, it is the home where girls/women learn about appropriate social roles.

Mirat-ul-uroos (2012) revolves around Aiza's decision to leave the joint family and establish a separate household, disconnecting her husband (Hammad) from his family at a time when they relied heavily on his income. Aiza and Hammad eventually regret their decision when their marriage falls apart due to Aiza's extravagant consumption habits and Hammad's extramarital affair. In contrast, Aima provides valuable counsel to her underemployed husband (Hashim), takes up waged work (tutoring students) occasionally to relieve the family's financial burdens, and through careful financial planning helps her in-laws repay their debts. She also secures a proposal for her divorced sister-in-law and tutors her brotherin-law when he is on the brink of failing high school examinations. Whereas Aiza is self-centered, spendthrift, desires material possessions, and eventually leaves the joint-family, Aima is pragmatic, frugal, adept at homemaking (managing a budget, cooking, and sewing) and strengthens the joint-family unit. These portrayals of femininities neatly align with Nazir Ahmed's characterization of Akbari and 
Asghari; a commitment toward familial harmony and loyalty to the patrilineal family thus appears as an ideal orientation for women.

The drama establishes Aima's and Aiza's contrasting womanhoods through a broad range of techniques. Aiza, for instance, is shown to pay too much attention to new styles of clothing, shoes, and makeup-which creates financial pressures for her parents and, later, her husband. She often appears in heavy makeup, wearing heels and designer clothes that do not call for a dupatta (a form of long scarf normally worn over a shalwar kameez by women in Pakistan as a sign of piety/ modesty). In contrast, Aima appears in shalwar kameez, dupatta, and slippers. Aiza's hair is dyed and styled in short layers, whereas Aima's retains its original color and is worn in simple styles, such as a low ponytail. We also often do not find Aima in heavy makeup-in fact, it sometimes appears as if the makeup artists intentionally try to create a pale look by deliberately lightening her lips! These visuals signal that being too engrossed in one's physical appearance, which often also entails spending extravagant amounts of money, is not ideal for middle-class women. Such practices are also linked with notions of middle-class respectability, where dressing modestly is a way to secure one's honor and not invite the male gaze. In fact, in the final episode, when Aiza reforms her ways, she also undergoes a physical transformation: she is shown to wear a dupatta, her hair is not heavily styled, and she wears minimal makeup. This transformation delineates the kind of reinvention that the drama calls on its female viewers to undertake.

There are many additional critiques of women's consumption habits which outline the practices that are at odds with the reproduction of the patrilineal middle-class family. For instance, early on, when Aiza and her grandmother (Akbari) decide to move in with Nasir (Akbari's son and Aiza's/Aima's father), their carefree use of electricity becomes a point of contention in the household. Aiza's mother-Amna-advises her daughter to be careful in her use of electricity, since "Pakistan is undergoing an energy crisis and the higher electricity bill will also put the household over the monthly budget." Aiza, as expected, scoffs at her mother's advice. Her spendthrift and carefree attitude becomes more problematic when she asks her parents to celebrate her wedding with Hammad with dhoom dhaam (elaborate festivities). The family does not have much savings, so considers selling a plot of land that they had acquired as a form of investment for retirement. Matters come to a head when Aiza demands a car in her dowry, which again puts pressure on their already overstretched finances. The elaborate wedding celebrations also cause Hammad's family to draw loans.

Aima, in contrast, refuses to demand a dowry even when her husband taunts her for not bringing as large a dowry as her sister. She critiques not only large wedding celebrations and dowry practices, but also the crucial role that women can play in breaking this cycle. Indeed, extravagant weddings that compel middle-class families to take on debt have become a norm in Pakistan in recent years. Many have argued that such celebrations not only create undue pressures for families but also lead 
to public nuisance and promote exhibitionism, which is contrary to the ethics of Islam. Consequently, the government of Pakistan has advanced multiple legislations to regulate wedding celebrations. In 2003, the Punjab Marriage Functions Act, also known as the Prohibition of Ostentatious Displays and Wasteful Expenses, established a rule that permits only one dish at wedding parties. As with other laws in Pakistan, this law has been slow to take effect-in fact, in the Geo TV production, there is a discussion around how helpful it would be if everyone followed this rule.

An interesting point to note, in this regard, is that while Aima's younger brother, Farhan, also refuses to ask for a dowry, his approach is represented quite differently. Farhan uses the language of religion (noting that these practices are unIslamic) to legitimize his stance. In contrast, Aima's preferences appear to be an effect of her concern for her parents. In other words, Aima wants to avoid a large wedding and extensive dowry because she is a conscientious daughter, whereas Farhan arrives at this decision as a thinking, rational man. Hence, women's critique of social norms is accepted, even praised, only when it is framed within the context of enhancing the welfare of the patriarchal family. Indeed, Farhan, too, could have adopted this stance against dowry out of a sense of responsibility as a conscientious son; however, that is not the case. He is portrayed as someone who arrives at this choice after careful and rigorous reflection on Muslim teachings. Aima's decisions, like Asghari's in Nazir Ahmed's text, are linked to her subject position as a daughter, wife, and, later, mother. In fact, Aiza who prioritizes her personal desires, interests, and ambitions is actively portrayed as a failed subject in Mirat-ul-uroos (2012). Women are called upon to reshape themselves for the reproduction, and financial and social survival, of the patrilineal family. This logic is also at play in the two sisters' stance on waged work.

After completing her master's degree, Aima decides not to work: "I thought

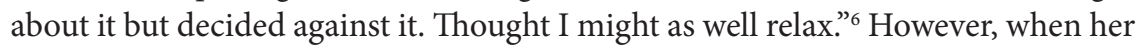
parents struggle financially after investing their savings on Aiza's lavish wedding, Aima decides to get a job. The following exchange between Aima and her father signals the specific conditions under which it is acceptable for middle-class women to work outside the home. It also highlights how talim (education) is understood in the contemporary Pakistani context:

Aima (to her father, Nasir): What's the use of getting all this education [talim] and then wasting it by sleeping and watching TV at home all the time? I was thinking about working until I get married; that way there will be some savings.

Nasir: What will do you with the savings?

Aima: What all girls do: collect items for a dowry.

Nasir: There is no need for you to prepare your own dowry. Beta [child], I'm alive. My situation is not such that I can't provide a dowry for you. 
Aima: I know. But I don't want to be a burden on you like Aiza. Abba [Dad], you gave me an education [talim] so that I can be independent. So now I want to take advantage of that education.

Nasir: You are a fool.

As discussed in the previous chapter, here too we find substantial connections between education and waged work. Aima offers to work because she believes that this will enable her to contribute to the family income, specifically to prepare her own dowry. However, she only offers to do so when her family is undergoing financial constraints. Readers will recall from the previous chapter that uppermiddle-class participants in my focus groups also wanted to acquire an education because it would enable them to earn an income if needed. Likewise, the two occasions when Aima chooses to work are linked with financial hardship (first her father's and later her in-laws'). As soon as her financial circumstances improve, she quits work and articulates a gendered division of labor that places the responsibility of providing for the family on men.

Let me illustrate this further. Aima convinces her father and secures a job that pays her quite well-Rs. (Rupees) 70,000 compared to the Rs. 50,000 that her future husband, Hashim, would make. However, she constantly complains about having to work hard all day long (khuwari), and yearns for the day when Hashim gets a job so that they can get married and she can "at least get rid of the job."7 However, Hashim is quite pleased with Aima's job:

Hashim (to Aima): It's excellent that you started working. After getting so much education [talim] it's not good to waste it. And I like working women; I don't like typical housewives-they just gain weight sitting at home, that's all.

Aima: Don't worry, when I become a housewife, I will not gain weight.

Hashim: What do you mean?

Aima: I mean that after marriage, I don't plan to work.

Hashim: Why?

Aima: I don't want to take on two responsibilities. Husband, house, kids are a big responsibility. And so I cannot take on the additional trouble of a job.

Hashim: What's the trouble with a job? There are many girls who work after marriage and manage their homes too. How do they manage?

Aima: Everyone is different; they may be able to manage both but I cannot. I cannot be that hard-working [mehnat-kasht].

Hashim (scoffing): Then be ready for all the household management to fall on you. You won't be able to have the luxury that Aiza bhabi [a term of endearment for a brother's sister] has. 
Aima: I am not in the mood to live luxuriously [ayashi]. I want to fulfill my responsibilities but by staying inside the home; outside responsibilities are yours.

The explanation that Aima provides for not wanting to work is not framed as a contestation of the double burden placed on women. Instead, she trivializes the struggle as one of personal preference- "Everyone is different"-and then responsibilizes women: if you are indeed a mehnat-kasht (hard-working) woman you can do both. It is this simultaneous opening and closing of subject positions in Aima's narrative that is instructive for how the patriarchal family provides space for women to engage in men's worlds while also regulating it. In other words, Aima's character shows that if there is no financial need, then middle-class women need not engage in waged work that requires them to leave the home. Such narratives preserve men's control over public spaces and women's bodies and labor. Women's labor then is available for exploitation in the service of the family.

We should also notice that it is Hashim (the lazy, underemployed husband) and not Hammad (the older, responsible brother) who advocates women's work. Hammad, the good son/husband, in fact discourages his wife from working outside the home. In other words, a good provider is one who creates the conditions for women to not leave the security of the home. This rhetoric further constrains the possibilities for women's work, especially for those women who do not have a choice in this regard. When ideal representations of femininity mark waged work as optional (as Aima said, you do it because you want to work hard) or temporary (you do it for a limited time when you need to), it becomes easier to dismiss the real struggles of low-income women in the formal and informal economies. Such narratives facilitate the withdrawal of the state from its responsibilities toward women. Women who are forced to work due to economic necessity are then often demeaned and find themselves in exploitative relationships and unsafe working environments. And, since the workspaces are male-dominated and unsafe, women who can afford to stay out of the workforce do so. Thus, a vicious cycle ensues that equates waged work with low-income familial status, inviting women's exploitation and in turn keeping women out.

Eventually when Hashim gets a job and the two get married, Aima quits her job. Coincidentally, Hashim soon gets into a fight at his company and quits his job as well. Unemployed, he tries to convince Aima to get back her old job or start working elsewhere. She adamantly refuses; she wants Hashim to fulfill his responsibility of providing for her: "In difficult times it is not necessary for a woman to work. It is important for her to support her man. I will help you find work but I will not take over your responsibility." ${ }^{8}$ On another occasion when Hashim cajoles her about getting a job, she notes, "I am your responsibility; you are not my responsibility." ${ }^{9}$ While there is an undercurrent that women should step into the workforce when their families are in dire circumstances, it is not acceptable to step in for 
reckless and lazy men, like Hashim. Here, the educated, samajhdar (intelligent) woman sticks to her predefined gender roles, compelling her husband to find a job. Later, when Hammad stops providing financial support to his parents and Hashim's income is inadequate to run the household, forcing her retired father-inlaw (Wajahat) and young sister-in-law to begin thinking about getting jobs, Aima volunteers to start working again as a part-time tutor.

Aiza's character is often deployed as a stylistic devise to lend credence to Aima's views. For instance, it is only after hearing that her sister is making Rs. 70,00o that Aiza thinks that she, too, should have worked after completing her master's degree. She is mesmerized by Aima's salary and mentions it repeatedly, which makes her appear greedy and jealous. This in turn calls on viewers to dismiss her interest in professional work as yet another frivolity. Aiza is again discredited later on when she expresses her desire to work after having children:

Aiza (to her husband, Hammad): I made a mistake. After studying so much, I should have started a job like Aima. ... I wasted time. I should have worked too. After our child is born, I will work then.

Hammad: Why do you need to work, especially after our child is born? It will just be a drain on you [khuwari].

Aiza: There are many people at home to take care of the child. And if needed I can get daycare services. But I want to work for sure since I get bored sitting at home.

Hammad: Then why don't you help out at home? That will make Mom happy too.

Aiza: A job is a job. Any servant can do domestic chores for only four thousand rupees.

Hammad: If a household is left for servants to manage then it does not remain a home.

In this conversation, Aiza clearly appears as the unreasonable one. First she wants to work because she is captivated by her sister's salary. Then she is ready to pass on the responsibilities of raising her child to her in-laws or daycare services, and when her husband tries to reason with her, she mocks him. While Aiza's arguments around working to establish a sense of self may be valid, they are framed as unreasonable since they involve displacing her responsibilities for her children onto others.

I see Mirat-ul-uroos (2012) as reflecting distinctly middle-class anxieties related to women's entrance in male-dominated working environments. These anxieties have to do in large part with workplaces being unsafe for women, and less about men's conservative/disempowering stances. Hashim, for instance, constantly cajoled Aima to work and "make use of her education." And while not welcomed wholeheartedly, neither Aima's father nor her in-laws stop her from working. Indeed, economic anxieties appear to be moving both men and women 
from adamantly refusing women's entrance into the workforce to a more tentative stance. However, Mirat-ul-uroos (2012) also displays the tension that pervades this social class as it struggles to reproduce its economic base while holding on to real and imagined cultural practices that middle-classness affords-such as maintaining a household with one male earner. It is precisely due to this tension that Mirat-ul-uroos (2012) fails to capitalize on its platform. Rather than calling for safer working conditions and higher incomes for women, it articulates nostalgia for a time when middle-classness could be reproduced without women's entrance into the workforce and, hence, valorizes a division of labor along gender lines.

Relatedly, Mirat-ul-uroos (2012) identifies specific cultural and social practices through which middle-classness can be reproduced. Readers will recall that in Nazir Ahmed's version, Akbari freely socialized with women from lower social classes (the hajjan), and suffered later, when the hajjan robbed her. Likewise, in Mirat-ul-uroos (2012), Aima and Aiza's contrasting views on appropriate social relations with men as well as those from lower-income classes demonstrate the type of interactions that are deemed (in)appropriate for the reproduction of middle-classness. One scene in particular illustrates these dynamics vividly. In it, Aiza and Aima are chatting in Aiza's bedroom, with Aima lying carefree on the bed without her dupatta. In that moment, their young male servant, Guddu (who is Aiza's servant and has come from Karachi to live with her in Lahore), enters the room without knocking. This startles Aima, who scolds Guddu: "You have to knock before entering any room. In fact, just hand us things at the threshold of the room." She gives him the example of her own servant (Sharfoo) who is not permitted to enter the bedrooms. When Guddu leaves, the following conversation ensues between the sisters:

Aiza: I asked him to bring me chai [tea]. He came in to give me chai.

Aima: Yes, but ammi and abba do not like it when mard mulazim [male servants] enter the bedroom. And that too without knocking!

Aiza: Excuse me [Aiza uses English here]. Mard? Mard mulazim? He has been with us since he was eight years old. He is barely fourteen or fifteen years old now.

Aima: Aiza, boys become very mature by the time they are fourteen or fifteen. And as I said, ammi and abba do not like when mard mulazim enter the bedroom.

Aiza: Why?

Aima: Sharfoo has been with us for years; but he only remains in the kitchen and the lounge.

Aiza: This is very strange. It means that you don't trust your servants.

Aima: It's not about trust; it is about household etiquette [ghar kay tarikay]. Aiza (scoffing): It's a very strange etiquette. 
Here, we not only observe Aima's views on gender relations, where she deems it inappropriate for men who are not mahram (unmarriageable kin) to enter women's private spaces, but also how it intersects with social class. Whereas Aima seeks to keep a social and physical distance between herself and those who work for her, Aiza consciously crosses these boundaries. On one occasion, when Aiza is watching a movie with Guddu, she is severely reprimanded by her mother. As proof that such an attitude toward servants is correct, we later learn that Guddu steals money from the household and runs away. The older servant, Sharfoo, who is earlier portrayed as exemplary, is also found stealing clothes, jewelry, and other items for his daughter's wedding. Hence, both servants eventually turn out to be untrustworthy, legitimizing the caution that Aima and her parents had toward them.

This storyline proposes that middle-class boundaries need to be constantly monitored for encroachment from lower classes. And it is women's caution (or recklessness) that is crucial in the cultural reproduction of social class. This is also the case when it comes to socializing with those who are above one's social class. Aiza, for instance, seeks to socialize with upper-class folk so that she can afford more opportunities to her son. To do so, she hosts expensive parties and buys designer clothes, and is tentatively successful in these efforts when she secures her son's admission to the Lahore Grammar School-a school accessed predominantly by the country's wealthy elite. Her husband, however, critiques her extensive socialization with the wealthy, noting that they cannot sustain it financially. Eventually, Aiza's aspirations for moving up the social ladder are squashed when her husband becomes fed up and is unwilling to fund her social habits any longer. The underlying message here is that women are responsible for managing relations up the social ladder as well as down.

Aiza and Aima's characters signal the kinds of consumption patterns, orientation to waged work, and gender relations desired to reproduce the middle class economically and culturally. Middle-classness, thus, is more than financial standing; it is, as Purnima Mankekar describes, "a moral virtue, a structure of feeling, the habitation of safe space that distinguishe[s] one from less fortunate (less worthy) Others, and therefore a vantage point on the world." ${ }^{10}$ Such virtue cannot be taught at schools. The differences shown between Aiza and Aima are not due to their talim (education) - both sisters completed their master's degrees. The difference lies in their tarbiyat (upbringing and nurturing), of which education in schools/universities is only one element. The broad concept of tarbiyat includes moral instruction that takes place at home, in which both immediate and extended family members participate. This instruction is often also influenced by religious principles. I therefore theorize tarbiyat as a discourse of governance that prescribes the kinds of subjectivities needed for the reproduction of the patrilineal family.

While what constitutes proper tarbiyat-like education-changes across the different moments considered in this book, it remains a discursive space through which individuals and social groups are able to critique competing discourses that 
seek to effect different youth subjectivities. This is clearly visible in Mirat-ul-uroos (2012), as well as Akbari Asghari (2011), discussed below. School- or universitybased education (talim) is seen as meaningful only in relation to accessing waged work, and not beyond it. Indeed, phrases such as "taking advantage of education," "education is an investment," or "using education" appear throughout Mirat-ul-roos (2012) to signify education's primary purpose. In contrast, the home is elevated as the ideal didactic space where young people learn proper dispositions as subjects of the family, the Muslim ummah, and the nation. This, readers will recall, was not always the case. Especially at the turn of the twentieth century, and less so during the first decade after the political independence of Pakistan, writers of Ismat, Khatun, and Tehzib did not view tarbiyat and talim as completely unconnected. Terms such as talim wa tarbiyat (education and upbringing/nurturing) abound in the archives. It is only against the emerging threat from English schools and the expansion of mass schooling that talim and tarbiyat fragment along different tracks and spaces. Aiza's and Aima's characters illustrate the completion of this process; while schools continue to partake in ethical training of youth, it is the home that is elevated as the primary site for the ethical formation of young people, which includes class sensibilities. In other words, the patrilineal family is the ideological site for tarbiyat.

\section{COMPLICATED FEMININITIES}

While Mirat-ul-uroos (2012) features contrasting performances as foils to elucidate ideal girl/womanhood, HUM TV's production Akbari Asghari (2011) portrays the diverse subject positions available to women, and so performs a subversive function in some ways. It takes several other bold departures from the original text as well. The sisters, Akbari/Becky and Asghari/Sara, grow up in England and are to be married to their uncle's sons, Akbar and Asghar, who live in a rural village in the province of Punjab in Pakistan. The different contexts of their upbringing (tarbiyat) appear as one of the central themes through which questions of what it means to be an "eastern girl" and "Muslim" are examined, which in turn are linked to concerns about the reproduction of middle-class respectability. However, in this version, the female characters are no longer entirely good or bad; rather, they are shown to be complex subjects who negotiate their personal desires with familial and societal expectations. Furthermore, while Becky and Sara remain the protagonists, additional female characters are carefully developed and given an extended storyline to show the diversity of women in Pakistan, as well as their varying concerns and investments. What we end up with, then, are figures who evade neat categorizations of good/bad or eastern/western. Readers should keep in mind that Akbari Asghari (2011) is a comedy production, which enables the writers and producers to exaggerate the characters and storylines for the purposes of entertainment and social critique. That the show utilizes tired, caricatured portraits of village people to elicit a comedic effect will be discussed later as well. 
In Akbari Asghari (2011), Akbari/Becky takes up the subject position of achi beti (good daughter) actively, while manipulating others into doing what she actually desires. Asghari/Sara, on the other hand, is frank and honest. She speaks whatever is on her mind, without fearing the consequences. Hence, Sara is seen by others to be harsh and is reprimanded by her parents for being selfish. For instance, on one occasion when Becky is late returning home after visiting her boyfriend, rather than letting her parents know, she manipulates Sara (who is also late returning home) into leaving the room without providing any explanation to her parents: "I will take care of it." When Sara leaves, Becky tells her parents that she was actually out looking for Sara. In this way, Becky hides her own faults while appearing to be a concerned sister. Her duplicitous personality is seen on myriad other occasions as well, especially when she tries to create chaos at her in-laws. She lies to her parents about her in-laws' mistreatment of her, hoping that they will ask her to break off relations with them and return to England. She fabricates stories about family members in relation to each other, creating distrust in the extended family. To be deceptive, superficial, and manipulative, hence, are marked as undesirable traits in women. The writer, Faiza Iftikhar, however, does not stop there. Rather than letting audiences deem Becky as an unsalvageable subject, Iftikhar uses the technique of internal dialogue to show that Becky is not oblivious to these tensions. There are several instances where we see her engage in a monologue, grappling with the imperatives of being the daughter that her parents imagine her to be while also hoping to do that which she desires. On multiple occasions, she admits that she is agreeable and polite because she does not want to hurt her parents, and because she desires praise- "I need praise and compliments; that's my addiction." These insights into Becky's personal struggles get audiences to empathize with her, resisting her reduction to a failed subject.

Likewise, Sara does not neatly fit the characterizations of Asghari as set out in Nazir Ahmed's Mirat-ul-uroos. While she is honest and caring, her parents criticize her forthright personality. Unlike Nazir Ahmed's Asghari, Sara consistently prioritizes personal desires and ambitions. For instance, to her parents' dismay, she initially refuses to marry Asghar. On another occasion, she dances at her sister's wedding in front of men-an action that brings shame to her family. She is also seen to socialize with female servants. Furthermore, she raises questions around public piety, eventually showing that a local religious figure was actually a charlatan. Hence, questioning sedimented class boundaries that have divided the Pakistani society, and exposing the hypocrisy of those who hide their greed behind religion, come across as courageous acts, as they are linked to a character whom viewers understand to be a "good girl."

That said, there are certain boundaries that Sara does not cross. Unlike Becky, who has a Catholic boyfriend, Sara resists the advances of her Hindu friend Raj, and in doing so articulates that some differences are indeed insurmountable. Whereas in Mirat-ul-uroos (2012), Aima thought that class differences could not 
be overcome, in Akbari Asghari (2011) Sara views religious differences in the same vein. Yet, when Akbar criticizes Sara for wanting to wish her Hindu friend on the occasion of Diwali, she contests his reductive understanding of religion. I will examine questions around religion and gender in detail later; for now, I want to point out the ways in which both Becky and Sara are complex, evading essentialized depictions as either good or bad. Viewers, then, are left with tentative assumptions about what kinds of performances are constituted as ideal, as both characters display the fluidity and tension that characterize women's everyday lives.

The fact that Becky's and Sara's characters are not one-dimensional is not a coincidence. In an interview, Iftikhar explains her desire to portray characters that break away from the binaries of good/bad: "[Television] channels just want heroines who make people shed tears. There is a trend nowadays to portray women in binaries-either very good or very bad, very intelligent or totally stupid, completely innocent or totally devious." ${ }^{11}$ Discussing Nazir Ahmed's Mirat-ul-uroos, Iftikhar complains that Akbari was always shown negatively because she was lazy and did not cook or sew as well as her sister: "Mothers and wives aren't the only women in the world. Many women are single or without children, so are they all bad women? . . . Should all women like Akbari just die off and only those like Asghari be heroines? Every home has an Akbari. . . . It doesn't mean that they can't excel in other things if they can't cook!"12 So Iftikhar notes her intention to create more complex characters: "It is easy to write about realistic characters. They are all around you." In addition to Becky and Sara, Iftikhar develops a broad range of additional female characters that provide insight into the multiple contexts in which women find themselves, and how they negotiate patriarchal norms. Through these intricate portrayals audiences come face to face with subjects who can be marked as neither ideal nor failed, but as fluid and in-the-making.

Consider the character of Bayji (also known as Baybay), Becky and Sara's aunt. She often appears next to the patriarch, her brother Chaudhry KFC, and given her age has secured respect among both male and female members of the extended family. Her story of personal tragedy highlights the tension women experience as they make a life within patriarchal systems. It was on her wedding day, after the signing of the nikkah (Muslim marriage contract), that her husband's family insulted her veer (older brother, Chaudhry KFC) in front of the entire baradari (community). Her brother asked her if she would let this insult stand. He gave her two options: to stand by him and not leave with her husband (that is, to postpone the ceremony of rukhsati, when the married woman officially departs with her husband), knowing that her husband will likely acknowledge his mistake and return to take her home; or leave with the people who insulted and dishonored him. Bayji decides to side with her brother, who, after all, had been her primary source of support after the death of their parents. Now, decades later, Bayji is still awaiting her husband's return (who eventually marries someone else). Throughout the drama, Bayji is often seen talking to her husband's photograph. At one moment 
in particular, she makes an astute observation while crying: "I neither thrived nor was destroyed. I didn't know that this was a fight between men, and not between a brother and a husband. In this fight between two men, I was left in limbo."13 Bayji's story provides insights into how relationships between men and women unfold in localized contexts. She prioritized loyalty to her brother over her desires for personal happiness in an environment where women's practices are intimately tied to familial honor. While her choices can be read as reinscribing patriarchy, it is significant to note that choices are always mediated by structural conditions. In this case, in spite of her wishes, Bayji chooses her brother's honor over her personal happiness. When Sara later criticizes her grandfather for not resolving his fight with Bayji's husband, he becomes aware of his mistake and makes amends. Akbari Asghari (2011), then, portrays complex gender relations, which are mediated by a range of factors, including assumptions about honor and a delicate balance between self and familial interests.

The characters of Becky, Sara, and Bayji shed light on the multiple contexts within which women move and the kinds of subject positions that are available to them. Rather than hold women exclusively responsible for their actions, Akbari Asghari (2011) shows how women's actions are an effect of a range of factors, which include histories, social commitments, loyalty, and responsibility. Women, thus, engage in what Deniz Kandiyoti has described as the "patriarchal bargain" wherein they "strategize within a set of concrete constraints."14 This assemblage of complicated female characters also gives insights into the pressures that Pakistanis and heritage-Pakistanis face as they forge new ways of balancing individual and familial interests. The desire for an ideal femininity is thus questioned and even suspended in Akbari Asghari (2011).

Even with this diversity of female subject positions, women in Akbari Asghari (2011) are only legible within the context of a patriarchal family, and it is the practice of marriage that marks one as a complete, fulfilled woman. This is clearly apparent in the final episode, which shows Chaudhry KFC resolving his differences with Bayji's husband (whose second wife has passed away) and leading her to rukhsati. Even though Bayji's character is forceful and powerful (she is, after all, the matriarch), and has a central place in the comedic production itself, she is ultimately represented as unfulfilled until she finds her true home-the husband's household. Happiness and fulfillment for women are staunchly situated within the institution of the patriarchal family. This is precisely the belief that was reflected by my focus-group participants; they, too, engaged in schooling in order to improve their marriage prospects and hence find a home they could call their own. Parent-participants in my study similarly wanted to educate their daughters as a way to secure better marriage proposals and to prepare them to become adept wives. The institutions of marriage and the patrilineal family, hence, remain central in Akbari Asghari (2011), even as it seeks to contest reductive portrayals of women as good/bad. 
In Akbari Asghari (2011), as in Mirat-ul-uroos (2012), we find a close link between women's performances of an educated subjectivity and the reproduction of middle-classness. We learn this through the character of Batool (Sara's and Becky's aunt), whose attempts at "appearing educated" through the consumption of expensive products and speaking broken English, make her a laughing stock. In contrast, Sara performs an educated subjectivity by calling out the hypocrisy of traditional customs and practices that marginalize women and might harm the patrilineal family. To be educated, then, is to be willing to simultaneously critique the ways in which local patriarchies constrain women and advance the welfare of the patriarchal family. It is a complicated balancing act that women must perform.

Batool, like her brothers, was raised in the village but marries into a family in Sialkot, a midsized city in Punjab. To mark herself as urban and educated, she constantly reminds everyone that she is from the "city" and tries to distance herself from her relatives who still live in the village. Her efforts to claim an urban/city status are criticized by her sister-in-law, who sneers that "after all, she is only in Sialkot (and not Lahore or other larger cities in Punjab)." There are myriad other ways in which Batool attempts to claim a middle-class, educated, urban subjectivity. She speaks in Punjabi but tries to include words in English at every possible opportunity, including transforming the words to fit Urdu sentence structures. She constantly asks her daughter (whom she refers to as "dotter") to translate Punjabi words into English. When her daughter resists the constant pestering, she reveals that she does so in order to appear educated vis-à-vis her brother's wife who has a bachelor's degree and lives in England. Batool consumes goods-expensive clothes, jewelry, and make up - to assert her nonrural status. She prefers to wear a sari, which, in this context, is perceived as a nonindigenous, cosmopolitan article of clothing. Her gaudy dress and mixing of languages elicits a comedic effect; however, it also illuminates how middle-classness in contemporary Pakistan is equated with the ability to speak in the English language, live in urban areas, and consume specific goods. Indeed, to speak in English is taken to be the ultimate marker of modernity (and hence, social difference), much as the writers of Ismat feared during the 1950s. It is through the practice of this language that the urban/rural divide is established. However, given the caricatured portrayal of Batool, Akbari Asghari (2011) calls on its audience to rethink its assumptions about middle-classness and "education." It offers Sara as an ideal educated, discerning, middle-class subject.

Sara tries to reform the customs and practices in the village that marginalize women. Her critique of her grandfather's neglect of his sister is an example of how educated, middle-class, and even foreign value systems (which are named as "liberal") can help reshape the customs of the village. On another occasion, Sara again appears as the voice of reason and stands up against patriarchal, duplicitous customs. This time she is running around in the fields having fun with some 
friends when Akbar passes by and reprimands her, because such actions "create a bad mahol [environment] in the village." He further notes that women should not engage with khas wo aam (special and ordinary) people in the same way. These boundary-making logics are often employed to restrict women's movement and create spaces of segregation. Akbar concludes: "Women have their limits." To this, Sara retorts: "What kind of limits are these that women cannot go around and enjoy as they desire? This is what makes the village's mahol bad? What about when women work day and night in the sun, in the rain, all day, in the fields? That doesn't create bad mahol? When this village's women, like men, can work hard in the fields all day and that does not create a difference in the mahol, then women can also go around and enjoy themselves as they desire." Sara, then, highlights the double standards at play that restrict women's mobility in some situations while encouraging it in others to exploit their labor.

Another instance of a similar critique of women's exploitation takes place when Sara chooses to dance with a professional dancer who has been invited to perform at Becky's wedding. Her entire family is ashamed, and her grandfather says, "Sharif girls do not dance with a street woman / professional dancer [bazari aurat]." While all men are shown to thoroughly enjoy the dance, it is only when their own female relative (Sara) partakes in it that they see it as an unwelcome consumption of women's bodies, calling the professional dancer gand (dirt). Sara picks up on this hypocrisy and asks: "Then why did you bring the gand (dirt) home? If she is a buri aurat (bad woman), why did you invite her to celebrate a happy occasion?" Sara's character highlights the hollowness of the family's claims to respectability and the politics of surveillance in relation to "honorable" women's bodies. That it takes a woman who has been educated in the West to critique and reform her family's attitude is a storyline that reinscribes the logic that only western values and education produce a sense of awakening. This, however, does not detract from the explicit social critiques that Akbari Asghari (2011) sets forth, as well as the positive valuation of those women who are forthright and speak their minds, willing to interrogate duplicitous attitudes and cross class boundaries. Sara's criticisms, however, are only tolerable because they further the purity of the patrilineal family (for instance, by calling on men to not seek pleasures with professional dancers), as well as due to her conformity with the prescribed ideals of a good Muslim subject (she refuses to consider Raj's proposals).

\section{THE TRIUMPH OF A MUTED RELIGIOSITY}

Discourses on ideal educated subjects have always been linked with discourses on ideal performances of religiosity. From the efforts of the Muslim reformers at the turn of the twentieth century to codify Islam, to present-day tensions around school curricula in Pakistan, religion has been invoked to articulate ideal female subjecthood. Given the role of religion in opening up as well as closing spaces 
for women, Akbari Aghari (2011) emerges as an interesting text that interrogates what it means to be a Muslim. Female characters-especially Sara-contest the ways in which religiously and/or culturally inspired discourses constrain women's mobility.

Readers will recall that the endeavor to reform women at the turn of the twentieth century was connected with clarifying what it meant to be a Muslim. Women's customs and practices were subjected to reform in order to demarcate an authentically Muslim identity, one that could be distinguished from the Hindu identity. In Nazir Ahmed's text, the figure of the hajjan (a woman who had recently returned from completing religious pilgrimage in Mecca) is revealed to be a charlatan, as the text sets out to caution its readers about those people who instrumentalize religion to prey upon innocent people. There is also an implicit effort to carve out and bolster the authority of the predominantly male ulama (religious scholars), who were being made increasingly irrelevant with the rise of colonial institutions. Authority was to be vested in the ulama and not the uneducated masses, and sharif women were called upon to become discerning consumers of religion. Akbari Asghari (2011) takes up religion in similar ways, elaborating on how some religious personalities are to be viewed with suspicion. The educated, discerning subject is able to detect religious charlatans from true believers.

The most evident way in which religion and religious practices are invoked in Akbari Asghari (2011) is through the character of Akbar. Akbar keeps a beard, is always seen in a prayer topi (cap), and often carries a tasbeeh (rosary). Instead of speaking in Punjabi like the rest of his extended family, he converses in Urdu with a healthy smattering of Arabic phrases and words. He dislikes dance, excessive celebrations at weddings, and prefers that women observe strict purdah. $\mathrm{He}$ keeps close company of a pir/murshid (religious guide), who is despised by other members of his family because they believe him to be a charlatan (which he, in fact, eventually turns out to be). Akbar's family mocks his appearance and social attitudes-on several occasions he is pejoratively called a "mullah" and his grandfather wonders how someone who is educated in the city would choose to return to the village to teach kids. Upon seeing him for the first time, Sara and Becky's parents go into shock wondering how this "Taliban will get past UK security officers." They worry that Akbar's comportment may bring suspicion upon the entire family in the United Kingdom. Likewise, when Akbar goes to the train station to pick up Asghari-who does not know what he looks like-she gets scared and imagines him to be a "Taliban." Recalling that incident later she notes, "I was really afraid and thought to myself that maybe he is from Al-Qaeda and wants to take revenge of America or London on me." These instances cast excessive displays of religiosity as unwelcome and unnecessary. Even Akbar's mother finds his religiosity unacceptable. On one occasion, after convincing his mother to see his pir's daughter as a potential wife for him, the following conversation about purdah ensues when they arrive at the pir's house: 
Akbar: Ammi [mother] wear the chadar [shawl].

Shaheen: I am wearing it. It is not locked up in a box.

Akbar: I mean, Ammi, wear it properly. Cover your head [his mother's head is covered with a dupatta-scarf-not the shawl]. You don't know. At the pir's household, everyone observes strict purdah. I don't want them to see you and then ...

Shaheen (raising her voice): Listen up! I am here to see the girl and not show myself off to your pir.

As noted earlier, the pir turns out to be fake-he dupes people into giving him money and is a pervert (he hits on Asghari) - which is yet another indication that true religiosity does not need overt displays and those who emphasize public performances of piety may in fact be impostors.

The kind of religiosity that the drama advances is one that informs one's values. For instance, when Raj expresses his love for Sara, she notes that their religious differences are insurmountable: "Even though I am not very religious, I cannot marry someone whose roots are different." This way of engaging with religion restricts it to a set of orientations and values, disconnecting it from active practice. In other words, Sara symbolizes a category of Muslimness where one does not have to engage in purdah or the rituals of regular prayer and fasting and can still be Muslim. This is clearly in contrast to the version of religion that Akbarand by proxy many Pakistanis-practice. However, Akbari Asghari (2011) rejects such enactments of religiosity. "Mullah Akbar," then, in many ways resembles the purdah-nashin from Asaf Hussain's text who were considered misfits due to their excessive religiosity. Today, it is the likes of Akbar-young, educated men, whose practice of religion calls for a serious commitment to prayer, fasting, and following the sunnah of the Prophet (by keeping a beard, for instance)-who appear to be in misalignment with the project of modernity. They are seen as outside the pale of recognition of ideal masculinity and are quickly named as "Taliban" - a term that signals extremist tendencies. Ideal performances of religion, according to Akbari Asghari (2011), entail keeping religion private; religion is to inform ethical formation and not public performances.

At the same time, while making fun of Akbar, Akbari Asghari (2011) also contests the reduction of religious people like him to "Taliban" and fundamentalists. Consider the following conversation between Becky and Sara, when Sara first learns that Becky will be marrying Asghar and not Akbar. Sara wonders why Becky rejected Akbar:

Becky: I think you have not seen Akbar closely.

Sara: I have met him. He is a little strange; his points of view and his thoughts are very different from us. But Becky, it is not necessary that those who are different are bad. 
Becky: You just want to oppose Mom and Dad regardless of whether or not you have any logic. And, how would I have been happy with a maulvi [religious leader]?

Sara: Why? Can't the wives of maulvis be happy?

Becky: By the way, why are you taking his [Akbar's] side? You only say namaz [prayer] once a year, that too in Ramadan.

Sara (in a mocking tone): And since you say namaz regularly, why do you dislike him?

Becky: Hello. I limit religion to myself, to my person [zaat]. And Akbar? Fundamentalists like Akbar try to impose their views on others. Even though you are so liberal, you are asking me to be with someone like Akbar.

Sara: I am a liberal, which is why I am giving into logic. The people who have Islamic views and that's the aim of their life, they are seen as fundamentalist; and the people who oppose Islamic views and that's their aim, are they not fundamentalist? You know my friend, Shushma, she is a brahmin Hindu; Sandy is Catholic, and Jacob is Jewish. These are all dear friends of mine. They are not bad. Then why do you dislike Akbar so much?

In this dense exchange, Sara tries to recover the category of religious (including practices of religiosity that include public embodied performances) from fundamentalists and the Taliban by proposing that those who take religion seriouslylike those from other religious traditions-are not necessarily bad. She assigns this logical approach to her liberalism. In other words, to be liberal is to not blindly write off all religious people.

That Akbari Asghari (2011) takes up the theme of "good" versus "bad" Muslim is an effect of the broader surveillance of Muslims globally, ${ }^{15}$ and the consistent articulation of Islam as a political category rather than as a religious system of beliefs. Muslims are racialized and pitted against presumably western, rational, enlightened subjects. In public discourse today, Muslims often appear as backward, entangled in premodern sensibilities, and longing for a golden age of the past. Often, culture and religion are blamed for the mistreatment of women in the global South, as well as seen as causes of acts of terrorism and violence. Against this background, there has also been an effort to mark some Muslims as "good" and others as "bad." Muslims, too, are participating in defining this good/bad binary and the exchange between Becky and Sara is an example of that process. There is, hence, a simultaneous mocking of some categories of "religious"-those who are extremists, Taliban, fundamentalist, or charlatans (like the pir) —and an effort to reclaim religion from dominant meanings that reduce it to a political ideology by signaling it to be a site of faith. That this is done through women's narratives 
is not surprising; just as women are to play a crucial role in the reproduction of the middle-class patriarchal family, they must play a similarly important role in amplifying the correct image of Islam and forms of religiosity.

Relatedly, there is a class component to these representations of religiosity as well. As noted earlier, members of the urban elite dominate the television industry in Pakistan, and television programs are produced for the consumption of both urban and rural populations. While there is an increasing trend in Pakistan where both men and women are adopting a more overtly religious identity through the uptake of clothing items such as the burka, keeping a beard, and learning the Arabic language, this trend is predominantly found in middle-income and lowincome social classes. Hence, one way to understand Akbar's mocking (and tentative recovery) in Akbari Asghari (2011) and the downfall of the pir, as well as the eventual triumph of a more muted religiosity, is to interpret this as a distinctly elite, urban view of the ideal place of religion in public life.

This chapter has focused on the changing landscape in Pakistan, where economic precarities, pressures of transnational migrations, flows of capital and ideas, as well as demands for gender segregation and maintenance of social-class boundaries form the context within which different subject positions for women and girls become available. Since schools have become the most prominent didactic space, I read the television shows discussed in this chapter as reasserting the role of the home in providing moral instruction and ideal representations of gendered subjectivities. Both Mirat-ul-uroos (2012) and Akbari Asghari (2011) outline the performances-consumption habits, relations with members of the opposite sex as well as other social classes, orientation to waged work, and engagement with the patriarchal family - that can help secure the economic and cultural reproduction of middle-classness. These shows call on women to monitor their desires and reshape themselves into ideal daughters, wives, domestic managers, and religious practitioners. In doing so, they reinstall the patriarchal family as the regulator of women's morality. At the same time, television also affords the possibility to critique social norms. Akbari Asghari (2011), therefore, sets out to resist women's reduction to ideal/failed subjects, and lays out multiple possible life-scripts for women. In doing so, it rejects the caricatured portrayals of educated feminine subjectivities, pointing to the complex relationships at the nexus of which women have to make decisions. As public pedagogies, then, these television shows provide insights into the contested making of ideal female subjects in Pakistan. 